Em primeiro lugar, preciso dizer da minha satisfação de poder estar aqui comemorando, com a minha família da FAU, essa possibilidade que hoje se realiza. Acho muito importante comemorar a nossa história que, certamente, é a história da gente que está aqui, que cresceu neste ambiente da FAU, sob a orientaçāo do Prof. Lauro. Mas também de vocês, porque a FAU é maior: é a graduação e, hoje, é a pós-graduaçāo.

Em 1948, ela começou como uma Faculdade no nivel de graduaçäo: em 1973 abriu seu curso de pós-graduação. Inclui, acredito, pratıcamente todos os que estão aqui e que têm um pouco do seu coração ligado à FAU. Isso nem sempre se pode comemorar, e essa é a minha satisfação. de um lado. Por outro lado, queria parabenizar o Prof. Ronca e a Pós-Graduação por essa iniciativa e pela possibilidade de conseguir que se desse mais um passo na ocupaçāo deste prédio, possibilitando ter uma sala própria para se receber uma visita, para apresentar uma tese com a dignidade que se está tendo no momento.

Queria também dar as boas-vindas ao Prof. Beylier, cuja conferência também lembra um pouco da nossa história. Quando foi inaugurada a Universidade de São Paulo não tínhamos professores e ele evocará a história da atuação dos professores franceses que estiveram aqui no início da historia da USP especialmente de Roger Bastide.

Com isto, quero declarar inaugurada esta sala, em honra do Prof. Luiz Ignácio de Anhaia Mello, e me congratular com os professores que estão aqui e com todos vocês. Muito obrigada.

\title{
Conferência do Prof. Charles Beylier sobre o "Pensamento do Sociólogo e Antropólogo Roger Bastide"
}

Quero agradecer o convite que me foi feito para participar desta inauguraçāo, pois tanto a homenagem ao fundador desta Faculdade quanto a renovaçāo deste prédio demonstram a preocupação que a diretoria da FAU tem em manter viva a memória.

A memória fica viva quando tem instituiçōes. quando tem prédios, quando tem arte, que mantem a história dentro das próprias linhas, lanto da Arquitetura. como também da pintura. Sabemos que não há história sem memória e um povo que perde a memória perde, portanto, a sua própria história, quer dizer, a sua identidade.

Assim, acho uma grande coisa quando passo na avenida Paulista e vejo prédios magníficos pela altura que eles têm e. ao mesmo tempo. graças a Deus, de vez em quando, no meio deles, uma pequena casa que ainda resistiu e que vem lembrar alguma coisa da História. Isso é o problema que enfrentam todos os países do mundo: manter a História do passado e construir o futuro.

Por isso, agradeço muito este convite e, sobretudo, a oportunidade de falar de Roger Bastide.

Nāo conheci Roger Bastide. Quando comecei a me preocupar com o problema da interpenetração de culturas em 1975, ele já tinha morrido e repousava no Cemitério de Anduze.

Tornel-me preocupado com este problema porque, vivendo desde 1965 em Campina Grande, na Paraíba, fiquei impressionado ao ver como as pessoas com descendência indigena ou africana e que estavam engajadas, naquela 
(1) Fique Impressionado pela rapıdez com que os cultos afro-brasıleiros se alastraram em roda $\mathrm{Pa}$. raiba com o aporo do governador de entao, tanto no Interior como nas cidades Parece que a semiclandesınidade em que eles estavam mantıdos aprisıonava uma misterıosa força cultural extre mamente profunda em todos os segmentos da sociedade paraibana quassquer que fossem as opçoes politıcas as raizes europelas, Indigenas ou africanas

(2) A prımeıra vez que Roger Bastıde viajou até a Bahıa e o Nordeste (patrocınada por Assıs Chareaubriand), ele escreveu um livro importante "Imagens do Nordeste Mistico em Branco e Pre. 10" O orıgınal em francês estava perdıdo e Henry Desroche me incentıvou a fazer uma traduçăo em francês que foı publıcada nas ediçoes Pandora Entre todas as obras de Roger Bastide este livro é certamente o maıs basılıano por ser um escrito poético, místıco e crentifico

época, nos problemas da cidade, nos problemas econômicos e políticos e muito comprometidas politicamente, de um dia para outro deixavam tudo isso e voltavam para os cultos afro-brasileiros ${ }^{1}$

Isto me intrigou e decidi, depois de dez anos, fazer um ano sabático para aprofundar um pouco o problema da interpenetraçāo de culturas.

Fui encaminhado ao Prof. Henry Desroche, discípulo do Pe. Lebret e Diretor das Ciências Sociais do Desenvolvimento na "École des Hautes Études en Sciences Sociales" de Paris. que me disse: "meu amigo, vou iniciar este ano um seminário sobre Roger Bastide e você vai participar" E. a partir de então. cursei e obtive meu diploma nessa escola ${ }^{2}$

Nāo sou um acadêmico tradicional, pois a École des Hautes Études en Sciences Sociales admite uma formação paralela à acadêmica, isto é, ela permite às pessoas que não passaram pelos canais normais da universidade, mas que têm competência pela própria experiência profissional, pela própria vida que tiveram, elaborar um trabalho que seja científico. $E$, de fato, há muitas pessoas que nāo puderam entrar ou nāo têm tempo para cursar a universidade, mas que têm capacidade de produzir conhecimentos, não só a partir de livros, mas também a partir do ensino que a própria vida nos dá.

Nessa Escola, uma pessoa que tenha somente o primário ou o secundário também pode ingressar. E vocês sabem que há muito mais gente do que se pensa com capacidade intelectual formada a partir da própria experiência.

Em 1976 ocorreu, aqui em São Paulo, organizado pelo Instituto de Estudos Brasileiros da USP um seminário sobre Roger Bastide. Eu participei a convite do Prof. Henry Desroche. Ali nasceu a idéia de criar as "Bastidianas" na França e aqui, para recuperar todos os escritos e a obra de Roger Bastide aqui no Brasil e na França.

Este projeto, que está andando, tem como finalidade permitir aos brasileiros conhecer, traduzida, a obra de Bastide publicada na França e, aos franceses, os estudos dele produzidos aqui.

Passei um ano pesquisando no Brasil todo. entre Porto Alegre e São Luiz do Maranhāo, a descobrir mais de 800 artigos de jornais, revistas e livros. Reconstitui praticamente toda a obra de Bastide, conforme orientaçāo do Prof. Desroche. De 850 textos, eu consegui 842 . Falta pouca coisa.

Consciente de ter nas mãos uma obra excepcional e desconhecida, admirado pela fineza e a profundeza das análises que abrangem toda a vida cultural, econômica, política da sociedade brasileira e da França. aceitei a proposta de Henry Desroche, de Maria Isaura Pereira de Queiroz e de muitos antigos alunos de Roger Bastide, de escrever uma tese de doutorado. Empolgado pelo trabalho, elaborei uma tese intitulada "A Obra Brasileira de Roger Bastide" Foi assim que entrei na Universidade, sem querer.

Eu agradeço muito a Roger Bastide essa oportunidade. Quem partıcipou da banca foi Pierre Monbaig, Pierre Auguste Bastide. Maria Isaura Pereira de Queiroz e Henry Desroche, quer dizer: uma brasileira. dois fundadores da Universidade de São Paulo e o último que era amıgo de Roger Bastide. O único que não o conheceu fui eu.

Tenho outras preocupaçōes. Para explicitar um pouquinho: eu sou padre também. Padre da Igreja Católica. em exercício. O fato de ser padre me ajudou muito a entender Roger Bastide e vou explicar por quê. 
Roger Bastide nasceu em 1898 e morreu em 1974. Era um homem do povo. Seu pai era professor primário porque, na França, muitos professores primários são homens, ao contrário daqui, onde a maioria é mulher.

O avô dele era ateu, revolucionário que não podia ver nem de longe os pastores protestantes e os padres católicos. Tinha raiva em relação à instituição de igreja, qualquer que fosse. O futuro sociólogo herdou dos seus pais o respeito e o amor do povo simples e o misticismo dos "Cévenols" Do seu avô ele herdou a chama do revolucionário, socialista, discípulo de Jaurés.

Roger Bastide nasceu em Des Cévennes, perto do sul da França, uma região mediterrânea, seca e fria no inverno e muito quente durante o verāo, onde passava suas férias de criança, na pequena cıdade de Anduze, onde sua avó tinha uma casa. Foi lá que, no tempo de Luis XIV. durante a perseguição aos protestantes, houve resistência destes ao exército do rei. O foco da resistência ficava nessa pequena cidade que tem uma ponte, onde os exércitos protestantes, formados por gente do povo, que nāo tinha instrução nenhuma, resistiam e lutavam por sua fé e por sua liberdade. Liberdade em poder ter a fé que quisessem. Nas pequenas comunidades. as famílias rezavam, cantavam salmos; surgiram profetas, um profetismo místico que desafiava os poderosos.

Na ponte de Anduze, ainda hoje pode-se ver os lugares onde as cabeças dos tenentes do rei foram espetadas. Vê-se também o Museu do Deserto, onde todas as lembranças dessa epopéia mística estão guardadas: os nomes dos mortos, dos condenados a trabalhos forçados e o nome do movimento (a palavra-chave) da resistência dos protestantes: "RESISTANCE"

Para esse povo protestante. essa história, hoje, e uma história viva.

Ilustrando esta história, quando estive lá, o ex-chefe da estaçāo ferroviária, hoje desativada, muito amigo de Roger Bastide, afirmava categoricamente que este nasceu em Anduze. Na realidade ele nasceu em Nimes. Mas Nimes capitulou, se entregou ao rei. Anduze não.

Nessa resistência nasceram generais e profetas da subversão, e começou a haver um grande surto de misticismo, isto é, um profetismo místico extraordınärı.

Quando Roger Bastide chegou aqui, em 1937 e tomou contato com o candomblé, a umbanda. essas religiōes sincréticas proibidas: quando ele descobriu a história dos quilombos. a resistência dos negros para defenderem a sua cultura, a sua dignidade. a sua fé. a sua religiāo e. portanto, a liberdade. ele ficou empolgado. Para ele, isto era como se fossem duas resistências que se haviam encontrado: uma na França e a outra no Brasil. E para defender a mesma coisa: a fé e a liberdade.

Foi a partir daí que ele começou a entender que o sincretismo é a coerência de uma fé que não corresponde à nossa formação ocidental. Sincretismo não seria apenas o aglomerado dos pedaços que sobreviveram àquela época em que eles estavam na Africa. Roger Bastide pensou: "ai deve existir uma coerência" e após ter estudado tudo o que foi escrito no Brasil e na América Latina sobre esses cultos, ele começou a fazer suas próprias descobertas.

Descobriu que, na realidade, o sincretısmo é uma filosofia extremamente elaborada. É uma mística, é uma religião que é capaz de formar místicos tão grandes quanto os que nós conhecemos. como Santa Tereza d'Ávila e São Joāo da Cruz. 
(3) Nas duas obras principals, que ele escreveu para conseguir o Doutorado de Estado na Sorbonne. As Religioes Africanas no Brasıl (1960) e Candomblé da Bahia (1958) sáo aında hoje obras de referência sobre o problema das interpenetraçoes de civilizaçoes

14i Entre misticismo e literatura existe uma rela cao estreita A prosa e a poesia dos escritores e dos poetas revelam o que está escondıdo no in consciente coletıvo, aquilo que pode ser vivido sem ser "dıto", de tal maneira que a literatura pode ser o cam inho que leva a descobrir as espe cificidades de uma mistica A misilca, por sua vez nao encontra outro caminho para se expressar do que a evocaçáo poélıca Roger Bastıde que fol um profundo conhecedor da literatura francesa

(5) Os quatro artigos escritos sobre Cruz e Sousa sáo particularmente significatıvos da metodologia de Roger Basilde Convencido de que "a origem racıal dá lugar à formaçáo de certos traços proundos da personalıdade literárı" (A Candıdo 1993), ele mostrou como o poeta revela as suas orıgens negras através da cor, da luz e dos cabeos etc Grande escritor simbolısta Cruz e Sousa ao adotar o sımbolismo reinante naquela época, querıa na realıdade, mostrar o seu gênıo poético Era um protesio uma maneira de competir no terreno dos brancos
Seu primeiro livro escrito na França foi Problema da Vida Mística (1931) e o segundo foi Elementos de Vida Religiosa (1935). Assim, além da experiência pessoal como descendente dos "resistentes" ou por causa disso. ele tinha toda uma formação sociológica sobre o misticismo ${ }^{3}$

É importante delinear a distinção entre misticismo e vida religiosa, porque o misticismo é o misticismo da utopia e a religiāo a institucionalizaçāo da utopia.

O que interessa nāo é a instituiçāo, que mata o instituído, pois quer sobreviver a partir do instituido e que este nāo provoque problemas para ela. Por exemplo: enquanto a Teologia da Libertaçāo (que é uma maneira de interpretar a utopia cristā) produzia livros, nāo preocupou ninguém; a partir do momento em que os trabalhadores começaram a criar movimentos, tanto na Europa como aqui, partindo dessa Teologia, imediatamente ela foi proibida.

Aconteceu em 64 aqui e está recomeçando agora mesmo. O instıtuinte quer instituır: ou ele destróı a instıtuição ou esta o devora.

Roger Bastide começou com a literatura ${ }^{4}$ Os primeiros livros que ele publicoui foram Os Poetas Afro-Brasileiros (1943) e Poetas do Brasil (1945). Alem disso, publicou Arte e Sociedade (1945). obra mais teórica, Psicanálise do Cafuné (que vamos reeditar) e Imagens do Nordeste Mistico.

Ele estudou o estilo barroco, quando o descobriu no Nordeste e se encontrou com Lourival Gomes Machado.

Isso é interessante porque a literatura, para ele. foi um caminho para descobrir como poetas afro-brasileiros na realidade copiavam o tipo de romantismo que vinha da Europa, para mostrar que eles, negros, eram capazes de competir com qualquer autor branco.

Cruz e Souza, por exemplo, que é um grande escritor negro simbolista, fez questāo de mostrar sua arte como meio de revelar a sua capacidade de ser poeta. Quer dizer, por trás dos versos dele é possivel descobrir a alma do negro que quer ser considerado como pessoa, como gente. Era um protesto. Ele não fazia tanta questão de ser simbolista, mas queria competir no terreno dos brancos. Chegou a romper relações com sua māe, com o coraçāo sangrando, dizendo: "para ser fiel à minha mãe eu tenho que me tornar um poeta branco para mostrar quem somos nós, os negros" 5

Os estudos literários de Bastide ajudaram-no a descobrır o universo e a sociedade dos negros no Brasil no decorrer da História. Há várias fases que mostram muito bem, inclusive. uma história da literatura brasileira que vai ser republicada.

Ele fez isso porque, na França, realizou estudos sobre um judeu, um protestante e um católico, todos do Mediterrâneo. O judeu era Proust. o católico era A. Mauriac e o protestante era André Gide. Bastide mostra como descobrir, nos escritos desses autores, a sua mística. Ele estudou, nas obras desses três escritores, como o misticismo próprio de cada autor se manifesta através dos seus escritos. Este método deu resultados interessantes e, ao descobrir o encanto da literatura brasileira, tentou aplicá-lo também a ela. A mesma coisa descobriu com os poetas afro-brasileiros, especialmente. E também com as mães do candomblé, ele descobriu esse sincretismo, que nāo é uma mistura. Para se estudar o sincretismo é preciso partir do começo, que é o confronto do homem com a terra, porque ambos são uma coisa só. O Homem é um "Homem de uma Terra": os descendentes atuais de franceses, italianos. japoneses. alemães, foram marcados pela sua terra. Nós somos o fruto da terra. nós a transformamos, mas ela também nos modela. 
Bastide tem um texto sobre um poeta interessantíssimo, chamado André Lamandé, que nasceu numa regiāo de muita planta, muita chuva. muitos frutos, flores, verduras. E que se casou com uma moça que morava no Quercy. Bastide procura descobrir o que aconteceu quando ele deixou sua terra para viver com a esposa, em uma regiāo árida, onde há a beleza do sol que queima. Sobre isso, Bastide diz o seguinte: "o que caracteriza uma regiāo nāo é o conjunto de costumes, fragmento de uma evolução parada no seu "élan" dinâmico. mas são estes elementos duradouros que se chamam sol, clima, árvore e rocha: as coisas da terra" E ele acrescenta que: "a gleba é o torrão que modela seus habitantes, o sotaque, a cozinha, a alimentação, as roupas, a sensibilidade, os pensamentos, o imaginário e a mística" Quer dizer, o homem físico, intelectual e mistico que é modelado pela terra. Este é um ponto fundamental.

Depois desta descoberta, Bastide estudou Pascal, um físico cientista que tem uma grande obra sobre a epistemologia da ciência onde demonstra, como físico, que a verdade não nasce da verdade. A verdade nasce do erro e, portanto, é preciso descobrir o erro para poder avançar. A indução não é o único método para avançar, pelo contrário. às vezes, ela engana. Não vou retomar toda a história da indução.

O temperamento é também marcado pela terra. Há temperamento no qual o fator água é mais importante do que o fator rochedo. Ou então, o fator fogo ou ar. Então, a personalidade da gente é marcada pela própria terra onde a gente nasceu. Quando uma pessoa deixa a sua terra, sempre leva alguma coisa, tanto da constituição física, psíquica ou mística.

Lamandé escreveu um romance chamado "Teu país será meu" quer dizer: eu quero me identificar com o seu país, porque como posso amá-lo se não amar a sua terra, porque você e sua terra são uma coısa só. Nesse romance, ele conta a sua conversão para a terra da esposa.

Mas, ao mesmo tempo, tem coisas em Lamandé que não se converteram, que ficaram; de tal modo que ele também tem algo a transmitir a essa regiāo, que é uma riqueza que vem de fora. De tal modo que a região não é só uma fidelidade ao passado. É fidelidade também quando acolhe o migrante, o imigrante, permitindo a integraçāo desse migrante e a redefinição da sociedade a partir das migraçōes ou imigraçōes ${ }^{6}$

A sociedade brasileira tem que se redefinir como os alemães do Rio Grande do Sul, e lá não é uma província como São Paulo. São Paulo tem que se redefinir; só que São Paulo é um balaio de civilizações: tem os bairros dos judeus, dos asiáticos. dos italianos, como também dos nordestinos, dos mineiros. Cada um procurou reconstituir alguma coisa da sua terra, de seu país, de sua região... Plantaram árvores com as suas frutas, flores, plantas medicinais... Passeando nas feiras, nas ruas mercantís, os turistas, ao ver o que se vende, ao ouvir as músicas, ao cheirar o que se cozinha nas calçadas, pensam que São Paulo é um mundo em miniatura, um microcosmo das naçōes. É isso que faz a riqueza de São Paulo, que não está presa dentro da racionalidade ocidental. Ela vive uma dinâmica que é extraordinária, pois faz retomar todos os limites que podem existir dentro de uma região como a França, ou de qualquer outro país que gosta de viver sob essa racionalidade ocidental, para acolher as culturas mais diversificadas ${ }^{7}$

As culturas asiáticas, as culturas ocidentais, as culturas do Oriente Médio, as culturas da Austrália; todo esse mundo faz com que ali haja uma possibilidade de descobrir que a humanidade não é a humanidade da Europa. A humanidade
(6) As raízes de Lamandé subsistem, ficam vivas Elas resistem Apesar de ludo. Lamandé será sempre na terra do Quercy um "Outro" um que vem de uma "Outra terra" Diferente, Lamandé va assumir o que nele náo se tornou "Quercinors" e transmitir ao povo do Quercy uma rıqueza que vem de fora O migrante, o emigrante. "o estrangeıro" permite à comunidade que o acolheu e na qual ele procurou se integrar. redefınır-se reconstruir uma nova Identıdade, Iornar-se "Outra"

(7) Nınguém pode negar que a rıqueza econômıca. cientifica e tecnologica cultural e artístıca de Sáo Paulo broiou da coexistęncia exiraorainarıa das civilızaçoes, as maıs diversıficadas do nosso mundo As fronteiras que dividem as naçoes apagaram-se para permıtır uma convivèncıa fraterna voltada para a construçáo de um mundo melhor Năo se trata de justaposiçấo de culturas mas de uma integraçăo que favorece a crıalıvidade e a ınvençăo caracterísiıca de cada cuitura A bela nistoria de Sáo Paulo e a hisiória ora trágica ora gloriosa dos seus filhos indígenos africanos porlugueses. europeus, asiáticos ou orientais, um mosaico culiural vivo 
(8) O avanço clentífıco-tecnológıco fez com que o planeta se tornasse nossa terra A humanidade náo se reduz à civilızaçáo ocıdental A Nova Ordem Mundıal náo pode consıstır na domınaçăo de uma cultura sobre as outras sob pretexto de que uns seriam desenvolvidos e os outros subdesen volvidos For contra este etnocentrismo que Ro ger Basilde lutou a sua vida toda Neste sentido São Paulo e o Brasıl representam, no concerto das riaçoes, uma esperança. a de um Novo Hu manısmo que seja o fruto da partıcıpaçăo de todas as culturas sem perder a identıdade propria de cada uma

(9) Jorge Amado que o acompanhou nas suas visitas testemunha "Recordo a espantosa conversa entre ele e a máe pequena da Gomeia conversa que se desenvolveu num dialeto novo formado do francês e do nagó, onde reluzıam de quando em vez raras palavras portuguesas como presentes para nós Como se entenderam o so ciólogo francês e a mae pequena baiana, nao se até hoje é para mim mistério tăo grande quanto o da Santissima Trındade Mas a verdade é que se entenderam e esses negros aında náo tomaram conhecimento da situaçáo de estrangeiro de Ro ger Bastide Fol como um amigo, um Ogan branco, um balano bem balano, comedor de carurú e bebedor de aluá, que os negros receberam na sua intımıdade" (Amado, J 1944)

(10) Eie não viajou para a Bahıa com o objetıvo de entrar no candomblé O prımeıro passo da ınıcıaçăo para se tornar Ogan fol com a consagraçăo de uma harmonia preestabelecida, "o encontro de duas histórıas de duas resıstencias misticas. o dıálogo de duas geraçoes de antepassados cé. venols e africanos a comunháo de duas experiêncıas fundamentass do sagrado" (Beylıer 1977) Ogan, fllho de Xango (o Orıxá do fogo;. Roger Bastide entrou na solıdariedade da mistica africana Até o fım da sua vida, ele ficou fiel a algumas das suas obrigaçoes A sua inıcıaçáo fol uma "conversâo" ou a civilizaçāo não é a que o ocidente quer impor, dizendo que "aqui somos desenvolvidos e ali estāo os subdesenvolvidos"

Foi contra esse etnocentrismo que Bastide lutou a sua vida toda, para mostrar que o Brasil é o berço das civilizaçōes mais contrastantes e. por causa disso, tem a riqueza que poucos países no mundo têm.

Tanto é assım, que eu, que sou francês, que vim com o meu sotaque (vocês vão me desculpar por ele), quando voltei para a França, três anos depois de ter chegado aqui. tinha a impressāo de ser o mesmo homem. mas meus irmãos me acharam outra pessoa.

O Brasil transforma, não é apenas uma justaposição de culturas e civilizações. Há um fenômeno de integração de tudo isso. Esta é a riqueza do Brasil; a riqueza especificamente de São Paulo. Quando a gente revê a fundação de São Paulo com os migrantes, com os imigrantes, com aqueles que estão aqui faz muito tempo, percebe a história mais bonita do mundo, com uma capacidade de criação, de invenção, de administração, de produçāo, de comercialização, que só aconteceu, ao meu ver, por causa dessa diversidade de culturas, onde os italianos trouxeram uma coisa, os alemāes outra, os portugueses outra, os ingleses outra coisa e. no fim, deu o que São Paulo deu. Quer dizer: uma história que eu acho muito bonıta ${ }^{\varepsilon}$

A partir desse problema da terra. que me parece essencial, eu queria chegar ao que Bastide acha que foi a sua conversão. Porque quando Bastide chegou aqui teve que fazer como o poeta Lamandé, isto é: teve que se aculturar e. portanto, realizar uma mudança para que a terra daqui. com suas culturas. civilizaçōes, seu clima. tudo o que ela é, pudesse transformá-lo.

Então ele começou a descobrir como era e chegou à conclusão de que não poderia entender, de fora, as religiōes afro-brasileiras e sua coerência, sem entrar nelas, sem participar. Quando ele foi à Bahia, e ele foi várias vezes (acho que não foi na primeira viagem que isso aconteceu), tornou-se muito amigo das māes-de-santo e dos pals-de-santo, pelos motivos que já falei. E o nosso amigo Jorge Amado acolheu-o e ficou espantado em ver um homem vindo de fora, que nunca consegulu falar português. embora entendesse tudo, conversar com os pais e mães-de-santo como se sempre tıvessem sido irmãos. Jorge diz, em um texto, que nāo entendia o que eles diziam: era uma mistura de italiano. francês, português que de vez em quando. ele entendia ${ }^{9}$ Havia entāo uma empatia entre Bastide e as māes-de-santo; uma misteriosa cumplicidade mística se criou desde o primeiro encontro entre as mães-de-santo e o descendente dos Camisards.

Como Bastide queria se introduzir mais no candomblé foi procurar o Babalaô que jogava búzios para descobrir seu Orixá. O Babalaô disse que ele era filho de Xangô, que é o Deus do Fogo. A partir do momento que a pessoa sabe quem é o seu Orixá, significa que, de certo modo. ela já entrou na rede mística dos africanos, na mística africana ${ }^{10}$

Depois ele tinha que passar pela "lavagem do colar" O colar é feito de pedrinhas de qualquer material, que o filho-de-santo coloca no candomblé, e as cores são as de seu Orixá.

Para esse colar ter a força do Orixa. tem que passar pelo menos 24 horas mergulhado nas ervas da divindade, em cima de uma pedra que corresponde ao Orixá, para que a força Dele possa passar pelo colar através das ervas. Às vezes, através do sangue de animais, da pedra e da cor. 
Uma vez feito isso e que o maná, que é justamente a força mıstica que vem dos Orixás, passou para as coisas, ele vai receber, na cabeça, as ervas e o sangue que permitiram o maná. Este é o primeiro passo fundamental. Depois tem muitos outros, mas este primeiro é importante para mostrar uma coisa: o candomblé vê o homem inserido na Natureza. O seu corpo está imerso na Natureza: as pedras, as ervas, as cores, os animais, quer seja o ser mineral, animal, ou vegetal. O homem é inserido nessa realidade natural e o seu Orixá só pode entrar nele através da natureza, porque o corpo nasce da natureza.

Entāo é através dessa vegetaçāo mística, deste mineral também místico, desses canais da natureza que Deus atinge aqueles que Ele vai possuir. Por isso o candomblé é um culto ecológico, porque nāo tira o indivíduo da Natureza: pelo contrário. ele só pode descobrir de dentro dessa Natureza.

A partir daí. Roger Bastide procurou estudar essa coerência de que estou falando rapida e insuficientemente. Ele descobriu que existe outro tipo de conhecimento. Tem o conhecimento pela inteligência, tem o pela poesia (intuitivo) e tem um terceiro conhecimento, que é o conhecimento pelo corpo.

Eu conheço o meu corpo, com tudo o que sou e com o meu corpo inserido na Natureza. Quer dizer: o africano não diz "eu tenho um corpo" ele diz "eu sou o meu corpo, o meu corpo nāo é exterior à mim, eu sou o resultado do meu corpo"

Essa dicotomia nós vivemos e ensinamos: esse tipo de dualismo, que piora quando entra também a moral para dizer que a alma é de Deus e o corpo é do Diabo. Aí tem-se uma redescoberta da relação entre o espírito e o corpo.

Tive, recentemente. uma experiêncla em Fortaleza que vou contar.

Um psicólogo francês que tinha tudo: fama, dinheiro, adoeceu de câncer aos 34 anos. Entāo, como ele era psicólogo, começou a entrar em si, se descobrindo: "esse câncer deve ser de alguma coisa que é minha e nāo se realiza" E ele foi fazer um retiro de três anos na Ásia com um sábio.

Três anos ele ficou lá, conversando com o sábio... A sabedoria nāo é o discurso, a sabedoria é outra coisa, então eles conversavam simplesmente. Faziam alguns exercícios de relaxamento, de reencontro com o corpo.

Em fevereiro deste ano, ele veio a Fortaleza convidado por mim, porque eu orientava uma tese para a qual a sua presença era importante, e teríamos a sorte de poder ouvi-lo, porque ele hoje viaja muito e tem 80 e tantos anos. Nessa ocasiāo ele relatou que quando voltou lá do seu sábio, repassou todas as radiografias, tomografias, e quando se compararam as radiografias com as anteriores verificou-se que não sobrou nada, que ele não tinha mais nada.

Isso é importante para ver que, da mesma maneira que o corpo se desmantela, sempre porque o espírito lhe escapa, ele nāo encontra o espírito. Entāo há uma interferência entre os dois. Por isso. hoje. tem tantas pessoas que fazem exercícios.

A tese da minha orientanda era sobre o ioga, sobre os que praticam ioga. Ela fez uma pesquisa em toda a América Latina e descobriu que, para quem faz ioga, o problema nāo é emagrecer e ter um corpo mais sadio. O problema é encontrar uma filosofia de vida. se reencontrar com o seu corpo, o que é uma filosofia. Então, o conhecimento pelo corpo, essa vontade de se redescobrir como mar da Natureza, através do nosso próprio corpo é uma conversão.

A conversão de Bastide foi justamente para poder assimilar e ser transformado pela própria filosofia africana. Esta é uma filosofia que tem uma dialética 
(11) $\mathrm{Na}$ introduçåo a Estudos Afro-Brasıleıros (Bastıde 1973), o sociólogo explicıta o que ele entende por "conversão". "Eu abordara o candomblé com uma mentalıdade elnocêntrica e assim teria de "converter-me" a uma outra mentalıdade, caso quisesse compreendê-lo $\mathrm{Pe}$ dirıa que não houvesse equivocos quanto ao senlido de "converter" náo se trata de aceltar a exıstência de um pensamento pré-lógıco e de negar a unidade e identidade das estruturas mentaıs Certamente todos os homens săo idênticos porém o pensamento puro náo existe, pois no seu funcionamento ele sempre se colore segundo as exıgencias das diferentes culturas no interior das quals se desenvolve Compenetrel-me portanto que deveria no momento de entrar no templo. deixar-me penetrar por urna cullura diversa da minha A pesquisa cientifica exigia de mım a pas sagem prelımınar pelo rıtual da inıciaçáo " (Bastıde 1973)

(12) O problema fundamental diante do qual o cientillco se defronta é o da relaçao entre Ciência e Cultura A teoria do conhecimento náo pode e Cultura A teoria do conhecımento nao pode
ficai presa nos lımites da racıonalıdade ocıdental no mundo das ıdélas claras "Serıa precıso ir das ıdéıas claras às ıdéıas obscuras e confusas - do conhecımento "por ıdéıas" ao conhecımento pela carne O mundo da confusáo e da obscuridade que nossa cıvilizaçăo cartesıana rejeıta, ou maıs oxatamente considera como um conhecimento in lerıor, inadequado, um conhecımento de segunda ordem, consequentemente pouco digno de nos reter é uma outra forma de saber" O conhecimento pela carne náo es uma forma inferior do menta carne nao e uma lorma inferior do (B) "obra" do espirito. este espírito é organicamente lıgado ao corpo, náo somente ao cérebro e ao srgáos dos seniidos como lambem às visceras aos músculos e à pele $O$ corpo humano é intımamente relacionado com o mundo mineral, vegetal e anımal, ao mundo cósmico do qual ele recebe náo somente o que precısa para subsisur mas a própria vida Para poder analisar a complexidade de uma realıdade viva, onde o todo nao pode se entender sem a totalıdade orgânica dos elemenlos que o compóm onde cada parte náo pode ser dissociada do todo Roger Bastide forjou os conceltos que Levy-Bruhl tinha percebido antes dele o concerto de participaçáo e o conceito de cısáo

Na relaçáo entre o concelto de partıcıpaçáo e de cısáo resıde a essência do pensamento africano un jogo sutıl entre o diferente e o idêntico uma uusencia de tronteiras que liga as diferentes parausencia de tronteras que liga as diferentes parógica formal para enriquecê-la por uma dialétıca maıs abrangente do que a dialétıca marxista ao permıtır pensar a divisáo sem distınção, a desconınuidade na contınuidade, as oposiçoes dos contrários O pensamento africano é "um sistema de composiçoes de forças que serıa como um jogo de dialétıcas, de complementarıdades, de conilitos entre principios descontínuos" Mas nesta dialética náo há sintese Os elementos contraditorios năo desaparecem numa unidade superior Crıase entre eles uma harmonia "a unidade de um movimento" que une a vertigem da descida dos corpos até a terra e o da subida até a luz" (Bastide 1972)

(13) Sem dúvida, o pensamento sociológico de Roger Bastıde posterıor à sua "conversão" enriqueceu-se de uma antropologia e etnologia do conhecimento uma nova epistemologia Neste ponto ele vai ao encontro dos físicos modernos que constatam com muito realismo quanto que consiatam com muito realısmo, quanto a
cıèncıa da matérı náo orıenta para as noçoes clèncıa da matérıa náo orıenta para as noçoes conhecımento de nós mesmos de nossa estrutura enquanto seres humanos do que um conhecimento do mundo exterior ou de uma verdade eterna (Espagnat, Bernard d' 1981) Segundo a frase célebre de Heisenberg "A Clèncıa é apenas um anel na corrente ınfınıta dos diálogos entre o homem e a nalureza Năo se pode mass falar de uma natureza em si" (Id)

Pos - $R$ Prog Pos-Grad. Arquit Uro faUUSP Sáo Paulo n. 4 o $15-38$ dez. 1993 diferente da dialética da racionalidade científica ocidental. Quando Bastide dizia, por exemplo: "a pesquisa científica exigia de mim a passagem preliminar pelo ritual da iniciaçāo" pedia que não houvesse equívocos quanto ao sentido de se converter. Não se tratava de aceitar a existência de um pensamento pré-lógico, de negar a unidade e a identidade das estruturas mentais. Certamente todos os homens são idênticos, porém, o pensamento puro não existe, pois, no seu funcionamento, ele sempre se colore segundo as exigências das diferentes culturas, no interior das quais se desenvolve.

"Compenetrei-me, portanto, que deveria, no momento de penetrar no templo, deixar-me penetrar por uma cultura diversa da minha. Antes de penetrar no templo, quer dizer, no candomblé, eu tinha que me deixar penetrar por uma cultura que nāo era minha. Não podia ficar com uma mãe de candomblé sem me converter. Seria uma mentira" Bastide queria ser verdadeiro, entāo ele se iniciou. É isso ${ }^{11}$

A partir daí ele descobriu um outro tipo de pensamento. O pensamento africano, a filosofia africana, que é uma filosofia baseada em três principios: o de participação (onde participo de tudo o que é da Natureza), o de corte e o de correspondência $^{12}$

Esses três princípios, que nāo vou aprofundar, explicaram para Bastide o problema do sincretismo. Não é mistura: posso ser, simultaneamente, do candomblé, filho de Orixá, e da Igreja Católica. Porque sāo coisas diferentes e há entre elas uma relaçāo, que é a relaçāo da vida do negro o qual. ao mesmo tempo, tem suas raízes e vive numa sociedade católica. Entāo, para ele, não é confusāo. Para ele é a realidade que é assim e nāo adianta querer que ela seja outra.

Eu diria que Bastide nāo tem teoria, ele tem um pensamento sociológico, o que é diferente. Quem tem uma teoria defende-a, transmite-a. Ele nunca quis transmitir teoria nenhuma e não quis também ter discípulos, que só saberiam repetir o que ele dizia. O que ele transmite é que, não tendo o pensamento, ele está livre para acolher qualquer pensamento; porque ele nāo defende a sua própria posição, ele acolhe a dos outros ${ }^{13}$

Há um certo ecletismo, mas nāo qualquer ecletismo. Ecletismo que peneira o que vem de fora, não a partir das próprias idéias, mas a partir da realidade.

Quando vê que uma teoria ajuda a realidade, a entendê-la melhor, entāo Bastide a integra, porque é a realidade que manda e não a teoria. Isso dá uma flexibilidade. Um exemplo: ele era anti-durkheiminiano e morreu sem ser durkheiminiano. quer dizer. positivista. E tem muita gente que pensa que ele foi positivista, durkheiminiano, justamente porque, quando estudou os problemas de interpenetração das culturas, ele teve contato com os norte-americanos e com a antropologia cultural norte-americana. E viu que os americanos estavam interessados em saber como fazer para que os negros americanos se tornassem americanos do norte. Era esse o problema: como dizer a esses homens alguma coisa, para que eles se americanizassem em vez de ficar entre eles, lá?

Os norte-americanos começaram a fazer estudos na África e vieram aqui, ao Brasil, tambem, para comparar. Bastide viu que os norte-americanos estavam certos ao irem procurar, na África, a raiz afrıcana dos africanos da América do Norte. Mas eles pensavam que bastavam algumas soluções para os africanos se integrarem na sociedade americana. 
Roger Bastide analisou tudo isso e viu o que estava errado nos norte-americanos: é que eles tratavam os africanos como uma realidade morta, que não vive. O que vive é a América do Norte; os outros são objetos que têm que se integrar na América do Norte. Entāo, Bastide afirmou que a causalidade externa não e suficiente para explicar os fenômenos, porque o que se fizer, de qualquer maneira, vai ser reinterpretado e recriado pelos próprios negros. Portanto é necessário ligar um com o outro.

Ele era anti-durkheiminiano. Seu mestre, Gaston Richard, após ter sido discípulo de Durkheim, foi seu feroz adversário. Apesar disso, Bastide disse: "é preciso voltar a Durkheim para entender a causalidade, que é indispensável para entender a realidade como ela está se passando"

Bastide, ao mesmo tempo, se enriqueceu da antropologia cultural norte-americana, se enriqueceu de Durkheim, sem ser nem antropologo norte-americano nem durkheiminiano. Justamente essa flexibilidade é que permite a ele não se fixar dentro de uma teoria.

E, para terminar, eu diria que, por trás de tudo isso, há uma epistemologia. Estou preparando um livro sobre Bastide (não sei se vou chegar até lá), onde eu gostaria de mostrar que a epistemologia dele é uma epistemologia que justamente tem como finalidade um novo humanismo e como fundamento o pensamento não-ocidental. Quer dizer: o Ocidente, junto com o que não é o Ocidente, precisa se converter, se enriquecer, com diferenças de culturas, para criar um novo humanismo, que não será como antes, ocidentalizado, dominador, egocêntrico, mas que será o humanısmo da humanidade e não o do Ocidente 14

\section{Seminário sobre o "Pensamento do Sociólogo e Antropólogo Roger Bastide"}

\section{Prof. José Luiz Caruso Ronca:}

Agradeço a palestra do Prof. Charles Beylier, mas a nossa tarde não termina aqui. Nesse sentido, eu gostaria de saber se alguém tem alguma pergunta.

\section{Prof. Silvio Barros Sawaya:}

Há uma questão, hoje, muito importante entre os arquitetos, que é a redefinição do objeto da Arquitetura. A Arquitetura do edifício isolado se perdeu por volta do final dos anos 60. A partir daí, se vê duas correntes. Uma vai procurar a leitura da realidade da cidade, das suas tipologıas e a particıpação da populaçāo. Outra corrente insiste na Arquitetura do edificio. Isso quase provocou uma ruptura em dois sentidos, e hoje é um reencontro. Reencontro, por um lado, por uma crítica à dita "Arquitetura Moderna" e, por outro pelo esforço de conhecimento sociológico, econômico, antropológico e geográfico, criando maior base para o trabalho do arquiteto.

Parece-me que, hoje, ao mesmo tempo em que se projeta alguma coisa, se antecipa, tem-se que verificar a realidade. E é necessário ser muito maleável nisso; nāo se pode ser categórico, pré-classificatório: é necessário aceitar transformar-se no processo

Esses aspectos fundamentais que se colocaram na Arquitetura, ou que se obtêm através de uma verificaçāo científica, podiam ser entendidos como os tais arquétipos, que fazem parte do imaginário da humanidade. de cada cultura.
(14) Ao iermınar esta rápıda apresentaçăo do pensamento de Roger Basiıde, eu querıa salıen. lar dols aspecios de sua obra Sociologo do mis. tıcismo da literatura e da arte. ele fol também estudioso do folclore da psiquiatria social das doenças mentals, dos sonhos e das utopıas A heterogeneidade das abordagens năo deıxa de ter um eixo central a interpenetraçáo das civilıza. çoes A realıdade da vida social é múlııla Uma especialızaçáo demasıada pode prejudicar o avanço das ciencias socıaıs A interdıscıolınarida. de é uma exıgêncıa da cıência moderría Nesie pequeno ensalo o nosso proposito era aperias de apresentar uma possivel leltura do sociólogo. uma biobıbilografia em torno do tema "O Homem e a Terra" por ser um aspeclo pouco conhecido da sua trajetórı cientilica

A !nterdisciplınarıdade conduz a um novo objetıvo que é uma preocupaça constante do autor da Antropologia Aplicada (Bastıde 1971) Diante do desencanto anunciado por Max Weber, numa socledade mundial que pensou conhecer os segre. dos do progresso e do desenvolvimento se laz urgente a necessidade de camınhar para um novo humanismo As culturas nascidas no Oriente abrem uma esperanca para a humanidade No entanto nao há determinismo na Historia Flas podem ser recuperadas e integradas a uma socie. dade de consumo como elas podem linertar a sociedade dita moderna das correntes que ela mesma forjou A responsabilidade é partilhada por todas as culturas e civilizaçoes 
Se não formos capazes de interpretar esses aspectos fundamentais e básicos, arquetípicos, tanto da cultura e do comportamento, como da própria recriação constante da vida social, não conseguiremos fazer essa nova Arquitetura.

Pelo que senti da sua exposição e pelo que me lembro das preocupações de Roger Bastide, me parece que ele antecedeu, em muito, a isso, justamente quando ele aceita ser maleável, para chegar a um certo imaginário básico. Acho que em Arquitetura não temos essa maleabilidade.

Será que não se poderia, numa releitura de Bastide, encontrar hoje, esses elementos básicos na cultura brasileira, tentar redescobrir esses arquétipos, ou essas estruturas básicas, e encontrar uma maneira brasileira de ser, nāo necessariamente ocidental, mas que pode ser mundial e antecipar alguns aspectos de uma sociedade mundial em formação?

A questão, complicada, no fundo não é uma questão, mas uma preocupação e uma oportunidade. se o senhor pudesse falar a respeito.

Prof. Charles Beylier:

Não é muito fácil, mas talvez seria interessante começar com uma pequena reflexão, a partir de dois artigos de Bastide, onde ele mostra que a cidade vertical é quase uma obrigação porque o problema do espaço é um problema real; como São Paulo não pode se estender, já se estendeu até demais, então compensa esse problema criando prédios muito altos.

Bastide faz uma comparação com a França. onde os prédios são um pouco menores. De qualquer maneira, nos dois, três ou quatro primeiros andares fica a burguesia: em cima, a classe media e. debaixo do teto. as empregadas da casa. O que ele notou, aqui, é que a estratificação que corresponde à sociedade francesa não corresponde à daqui, que è uma sociedade ainda muito familiar, com o sentido da familia mais amplo.

Os filhos, os pais. os avós, e a empregada da casa; todo mundo partıcipa da familia. Bastide ficou feliz de ver que isso toi respeitado mesmo nesses prédios muito altos, onde toda a família se encontra e não há. portanto. esse tipo de estratificação. Isto me parece um aspecto interessante.

Sobre o problema que você levantou, há um outro aspecto também, que é o de poder sonhar. Um povo que não pode mais sonhar, mesmo quando está em casa. é um povo que pode adoecer: o sonho é fundamental. Bastide ficou também feliz de ver que as janelas ocupavam a parede toda. quer dizer: há muito mais vidros, pelo menos em São Paulo, do que antes. Bastide nota que o fato de ver longe. de ter horizonte, e de nāo ficar numa caixa. è o aspecto fundamental para a convivência da própria família. Porque quando a mãe da família, que está lá quase o dia todo. só tem paredes ou então os predios do outro lado da rua como horizonte, acho que é desumano mesmo.

Além disso, na disposição dos quartos, da sala de reunião da familia, Bastide nota que há o espaço para o encontro da família, o encontro com as visitas, há um espaço muito grande. Isto é também um sinal de uma família aberta, que acolhe.

Sobre a disposição, ele verificou que na distribuição do espaço no apartamento horizontal (aliás, às vezes ele é horizontal e vertical ao mesmo tempo), não sei que estratificação è essa: são as crianças que estão em cima, para os avós ficarem embaixo...

De qualquer maneira, acho que aí há um aspecto essencial: pode-se encontrar um ambiente que seja "um ambiente" Agora. uma observação: os móveis tomam um lugar enorme. de tal modo que as lembranças da família, os retratos. uma pintura, às vezes nāo têm mais espaço para poderem ser coloca- 
dos. $E$ isso também parece um ponto importante. porque um quadro bonito. uma toalha bonita, também alimentam a imaginação.

Além disso, há o passado da família: o retrato do avô, da avó, do bisavô, dos amigos que já faleceram e que a gente quer guardar. Os objetos de arte também não têm mais lugar. Temos armários embutidos, televisão, minicassete, vídeo... Bom, temos que ter tudo isso, mas onde é que o passado da família vai poder se tornar uma coisa visivel? São algumas reflexōes...

Prof. José Luiz Caruso Ronca:

Prof. Charles, quero colocar a problemática do desenvolvimento em face da Antropologia. Ouvindo sua palestra, quando o senhor falou sobre o que é instituído e o que é da instituição. pergunto: o desenvolvimento sustentado também não e uma utopia, no sentido de nós estarmos trabalhando com alguma coisa instituída distante da realidade? Como o senhor vê ısso, face à sua visão antropológica?

Prof. Charles Beylier:

De fato, eu tive a mesma impressão. que o problema era tentar conceituar utopia e é próprio da utopia ultrapassar-se.

Mas quando pensei sobre esse problema, tive como impressão que muita gente gosta de palavras, de discursos, de conceitos, etc... E, parece-me que a urgência do problema pode esconder o que há por de trás do mesmo.

Então me perguntei: por que é que há planejamento e por que surgem problemas entre planejamento e planejado? O que está por trás desse conflito, dessa dificuldade de fazer um desenvolvimento sustentavel e que se sustente? Como é que ele pode se sustentar se o povo não se sustenta?

Gostaria de lembrar uma coisa. que me parece importante: estamos atualmente vivendo uma época extremamente interessante e ambígüa, porque é uma época de transição e ninguém sabe para onde val. Ninguem pode dizer.

Quero voltar ao pensamento dos gregos, quinhentos anos ou mais antes de Cristo, para !embrar que lá, na Grécia, também havia clêncıa; lá foi o berço da ciência, nāo é? E o desenvolvimento da ciência se discutia com sábios, na praça pública, que conversavam entre si para saber o que era bom fazer para que a cidade pudesse viver feliz. Havia escravos, também naquela época, mas o problema é que a dominação do Homem sobre a Natureza era controlada pelos proprios sábios que representavam a comunidade. O Saber Técnico era um saber controlado pela comunidade

Acontece que o desenvolvimento da ciência. naquela época, realizava-se em um ritmo que não tem mais nada a ver com o desenvoivimento da tecnologia e da ciência hoje. Atualmente, o desenvolvimento tecnológico ocorre com uma rapidez cada vez maior: quanto mais descobertas se fazem, mais veloz e ainda a evolução da ciéncia e da tecnologia. Resultado: a ciência tornou-se "autônoma" em relação à própria "comunidade" Ela se desenvolveu por si mesma: o motor da ciência está dentro da própria ciência.

E não somente a ciência se desenvolve de maneira autônoma, mas em vez de ser controlada pela "comunidade" é ela. a ciência, que vai impor à "comunidade" as suas normas: que vai impor à "comunidade" como ela deve viver. o que ela deve aceitar! isto porque a ciência passou a ser a razão de ser da "comunidade"

Então, essa autonomia tornou-se uma dominação do homem. da "comunidade"! Este é. a meu ver, um dos grandes problemas atuais. porque. de um lado não se pode evitar que as descobertas e os projetos tecnológicos continuem: 
de outro lado, não se pode assistir passivamente à dominação da "comunidade" pela ciência.

Além desse crescimento da tecnologia, há um outro aspecto que gostaria de destacar: a generalizaçāo do projeto tecnológico. científico, etc. Em outras palavras. o produto da ciência tende a unificar a Humanidade; você fica no Brasıl. ou val à França. a America do Norte ou a Alemanha, você verá todo mundo de jeans, de cabelo curto... - quer dizer: há uma moda há costumes. há valores que vão se comunicando através dos meios de comunicação. de tal modo que o mundo diminui de tamanho. o mundo entra na sua casa.

Essa generalização tende para uma estandartização, que, portanto, carrega com ela uma nova concepção da vida. A vida muda, a família muda, os valores mudam, a sexualidade muda, tudo muda.

É preciso saber que estamos num momento de transição e que, portanto, nāo se pode encontrar soluçōes que sejam definitivas.

Agora, diante dessa mudança, parece interessante justamente notar que a sociedade reage. Ela reage. não fica parada, exatamente como o corpo faz, quando as condições atmosfericas mudam. O próprio sistema do corpo humano muda também. A gente se adapta.

Eu queria colocar três sinais: o primeiro é que numa época de estandartizaçāo. as minorias culturais reınvındicam o direito que elas têm de viver. Se você observar: o Rio Grande do Sul quer a independência; o Canadá tem um Canadá francês que quer ser livre; na Rússia há um esfacelamento de todas as minorias que querem voltar a ser o que elas eram; na França, a Bretanha não quer ser separada, mas também não quer ser como qualquer outra província; cada província da França quer reencontrar a sua identidade e as próprias raízes. Aí se encontra um tema bem "bastidiano"; é que a terra cria uma cultura.

Isso tem conseqüências também sobre a Arquitetura, porque se você constrói num bairro de judeus, você vai ter uma problematica um pouco diferente, que devera ser levada em conta. tambem. e assim por diante.

Entāo na um regıonalismo que é extremamente interessante para permıtır às pessoas reencontrarem suas raizes culturais.

O outro aspecto: normalmente, com o desenvolvimento da ciência. tudo o que devia ser religioso, deveria desaparecer. não é? Ao contrário do que está se passando. Atualmente todos os conflitos no mundo são conflitos religiosos. É um fato. Até na Bósnia é um problema muçulmano; na Rússia, também; quer dizer; não há uma guerra que nāo seja religiosa; na Irlanda, etc.

Isso também é um aspecto que me parece importante: o sagrado é uma dimensão do nomem! O sagrado é dele. o homem fabrica o sagrado de qualquer manerra.

Portanto, o sagrado se manifesta através de guerras, movimentos. Por exemplo, na Igreja Católica existe o Movimento Carismático, que, a meu ver, é muito problemático, porque desenvolve uma espiritualidade que tem coisas boas: de um lado. escapa ao controle dos cléricos, do vigário. dos padres: a pessoa dirige-se diretamente ao Espírito Santo: de outro lado, ele é terapêutico porque permite que muitas pessoas, que vivem um drama interior, encontrem uma maneira de extravasar, de dizer o que tem dentro. Há um aspecto comum a qualquer religiāo: ser uma terapia.

Há, além disso. a utilização política, feita da ligação com outros movimentos, porque o religioso sempre é, para o político. um chão fértil, um campo impor- 
tante. Todo político vai à caça de qualquer religiāo, porque nela há uma freguesia segura.

Acho, além disso, que há o sagrado aberrante, que se torna loucura. Um exemplo: há pouco tempo aquela seita que se suicidou, em massa. É um fenômeno que deve ser levado em conta: a loucura também é a doença do sagrado

O terceiro ponto é o surgimento dos movimentos populares no Brasıl. A cldade se tornou o palco onde o povo vem dizer o que ele quer. Ai não sāo mais os sábios não, são as crianças que vão à rua para se manifestar, são os alunos do colégio, são os universitários, são os aposentados, são os advogados... Lá em Fortaleza, uma grande parte dos profissionais foram à rua... à rua, à praça pública... Aqui em São Paulo, a praça da Sé, a avenida Paulista tornaram-se locais onde o povo diz o que ele é, o que ele quer.

Às vezes, então, deseja-se saber o que o povo é e o que quer - eu não disse que ele quer, só o que ele vem reclamar. Mas o que ele vem reclamar supōe, primeiro que há uma organização. porque ninguém vai à rua sem estar ligado a um grupo: um imperativo interior. pessoal, que é o que há em cada indivíduo.

Acho que todos esses são sinais de uma contramodernização: diante de uma ameaça à sociedade, esta segrega seus anticorpos de tal modo que possa sobreviver, apesar dos desencontros entre a ciência e a comunidade.

É quando a sociedade procura encontrar o seu papel.

Prof. Lauro Bastos Birkholz:

A sociedade reage quando encontra elementos que nāo the satisfazem; então. como encararıa um programa de desenvolvimento planejado que evidentemen. te não possa ser discutido com a comunıdade?

Gostaria de saber o seguinte: é correto um grupo de pessoas tentar dar uma soluçăo no sentido de melhorar o nivel de vida da sociedade? Esse grupo pode não ter a certeza de que aquilo que vai fazer, dará certo. Então, com medo de que não dê certo, ele nada faz.

O senhor acha conveniente alguém fazer e agir apesar de saber que o seu resultado possa não ser totalmente satisfatório? Isto, porque ninguém tem a previsão ou pode saber de antemão o que a sociedade vai querer. Ou, então, ninguém pode esperar que a sociedade resolva, por si, os seus problemas.

Acho que isso nós nunca vamos conseguir. A própria sociedade, em si, só pode dizer o que tem que ser telto através de seus líderes, e será que estes representam a sociedade ou alguem pode propor uma reforma. ou um tipo de solução. mesmo com medo de que aquilo não seịa correto?

Prot. Charles Beylier

A pergunta do senhor é interessantissima e muito complicada. Não pretendo dar uma resposta certa: quero dar minha opinião.

O que quero dizer é parte do que eu vivı, isto é, dos fatos. Acho que estamos em uma situação em que só experimentando sabe-se o que dá, o que nāo dá e por quê dá ou não. E nunca dá perfeitamente, mas acho que é importante partir da experiência. Faz-se uma experiência numa rua, num projeto de construção de um bairro, de um prédio.

Acho que é um problema de exercício da democracia. O povo tem que dizer. ele tem que aprender a dızer. Ele nāo toı convidado nunca. Então nāo é de se estrannar se é a primeira vez que ele vai se reunir e oferecer suas idéias.

Gostaria de falar de experiências. De uma. eu participei, há um certo tempo, numa favela. fruto de uma invasão numa área nobre. Era um terreno de relevo 
acidentado, meio escondido. Ninguém viu a invasāo. O dono acordou e tentou expulsá-los. Então eu fui chamado a ajudar, porque senão os invasores seriam expulsos. Para mim, a terra é para o povo morar. Portanto, achei que era minha missão fazer com que eles se organizassem. Entāo ele se organizaram.

Havia naquela época, em Campina Grande, uma turma de planejadores urbanos. Era uma equipe excepcional. Tão excepcional que chamou a atenção de Macnamara, quando este era Presidente do Banco Mundial. E o projeto de Campina Grande, dessa equipe, que começou a se realizar nessa favela chamada "Pedregal" era um projeto não somente para dar a moradia, mas para dar a possibilidade de viver através de um pequeno artesanato, que eles mesmos fariam.

O problema da moradia nāo é só a moradia, é a sobrevivência. Portanto, quando se resolve o problema da moradia sem resolver o problema da sobrevivência, nāo se resolve coisíssima nenhuma, porque logo que precisarem de dinheiro, os favelados vão vender a sua casa e construir uma favela em outro local. Com o capital, eles vão poder até colocar uma banquinha para vender um pouco de carne, etc... e pronto!

O problema da sobrevivência é o problema fundamental. Lá em Campina Grande os favelados tinham todo um projeto; não somente de organização, mas até de traçado urbano sobre o qual refletiram: as ruas não eram retas, nāo se cortavam com um ângulo de 90 graus pois, como os planejadores falavam: "as ruas deveriam ser dispostas conforme o relevo do terreno" $E$ isso era importante justamente porque permitia as águas correrem, sem destruir o terreno.

Os planejadores ajudaram os favelados. Assim. estes elaboraram o projeto, junto com os planejadores, que iam lá duas vezes por semana.

Mas esse projeto não foi para frente, porque havia um grande projeto, com milhões de dólares da América do Norte, a fundo perdido, para todas as favelas de Campina Grande.

Então resolveu-se fazer um seminário, para o qual convidamos a Eva Blay para participar, juntamente com outros 100 alunos e 50 professores de todas as áreas do conhecimento: de Português. Biologia, Educação, etc.

É bom para o povo, para os planejadores, apoderar-se do projeto e reformular - projeto. em função do que eles pensam e também para que eles possam descobrir por que é importante ter água com filtro, ter água encanada, ter sanitário, e assim por diante. Quer dizer: uma educação do povo para eles viverem, construirem e se transformarem no projeto.

Realizou-se aquele seminário e a equipe, que era de cientistas, os planejadores da Condeca. se apresentou dizendo: "nós achamos que essa maneira de trabalhar era a melhor" Fizeram uma apresentação do planejamento dessas favelas, sem esconder os limites e as questões que ainda tinham na cabeça.

Imediatamente, a Câmara Municipal interveio, dizendo: "como é que vocês, em quem nós confiamos, podem criticar seu próprio planejamento? Se ele não presta, por que entāo o fizeram?" O diálogo não foi possível por questōes pessoais ligadas à Câmara e à Prefeitura.

Aí acabou-se o projeto e o seminário não pôde terminar. Tivemos que parar. porque o reitor nos disse: "meus amigos, se a gente entrar em conflito com a prefeitura, uma vez que nós pertencemos a ela, vão nos jogar para fora: do reitor até o varredor" Devo explicar que, nessa época, eu era professor da Fundação de Campina Grande, que é municipal. Só posteriormente me tornei professor da Universidade Federal. 
Quero justamente mostrar que nāo há planejamento urbano neutro, ele não existe e tem sempre certa visāo política, e é essa visāo que, de fato, não foi aceita pelas autoridades.

Os fracassos também sāo interessantes, porque a gente aprende, não é? Mas o povo, os alunos e os professores estavam prontos para trabalhar, para que um plano se tornasse uma colaboração entre planejadores e planejados, isso não há dúvida.

Atualmente, eu poderia contar outras histórias... Há um projeto em andamento la no Ceará. Estamos trabalhando num conjunto habitacional.

Dois bairros constituem um conjunto. Conseguiu-se fazer um convênio com a Prefeitura, para que o povo nāo utilizasse a casa de moradia para trabalhar. Havia um serralheiro que fabricava as grades, as janelas de ferro, outro consertava televisāo, outro era marceneiro, outro consertava geladeiras; tudo dentro de casa!

Reunimos todo mundo e dissemos: "e se a gente criasse aqui um centro de microempresas? Todas as atividades reunidas no mesmo lugar, com coisas comuns, mas cada atividade com as suas repartições. Há um terreno e a gente poderia, então, ter as facilidades da microempresa. e vocês poderiam viver tranqüilamente em casa"

Além disso, cada um estava de acordo em ensınar sua arte a muitos meninos do bairro. O Senai se propôs a formar os artesãos para ensinar, porque eles sabem muito bem trabalhar, sem saber transmitir. Além disso, o Senai se dispôs a acompanhar não somente os artesãos como também os aprendizes, para que estes também pudessem (isso seria só um curso de iniciaçāo) continuar a trabalhar no próprio Senai, à noite, para completar a formaçāo profissional.

E o Senac também, porque as mulheres, dentro de casa, fazem bolos, fabricam roupas para crianças e adultos, etc. Eles formaram uma associaçāo que já foi reconhecida oficialmente.

Na véspera de saır de lá inauguramos. nāo o Centro da microempresa, mas um centrozinho onde eles teriam as aulas para poderem refletir sobre o aspecto tecnológico e também poderem se preparar para o segundo grau.

Para que houvesse ressonância política ante o prefeito do município, perante o governador, porque isso deve interessar ao governador, convidamos esses políticos. Mas como eles nāo haviam estado no início do projeto, não se interessaram, não deram satisfação, nāo apareceram.

É aqui que se encontra um dos problemas fundamentais: o que é participação para o povo? É ser manipulado pelos políticos, que consideram a participação como a integraçāo do povo ao pensamento dos planejadores, ou é o contrário?

\section{Prof. Ricardo Toledo:}

Tenho muita curiosidade em saber a sua opinião a respeito do papel que, atualmente. têm os Movimentos Evangélicos, essas seitas novas. Toda a experiência que o senhor relatou é sempre na direção estruturante; quer dizer, os movimentos que agem junto com a Igreja Católica, os movimentos cristãos realmente têm um sentido estruturante da participação política, social, etc... Em outras palavras, existe sempre a admissāo de uma intermediaçāo entre a vontade, a necessidade individual e o seu cumprimento através de uma entidade social coletiva. A Igreja Evangélica, por outro lado, nāo! Essas seitas, que estāo surgindo, se propōem a fazer uma ligação direta entre o indivíduo e a divindade, digamos. E hoje é uma plataforma política não desprezível o papel que tem a bancada evangélica no Congresso Nacional. Essa bancada tem tido 
um comportamento do tipo mais conservador. para nāo dizer reacionário. dentro de qualquer movimento de cidadania, de direitos sociais.

Então, eu queria saber como o senhor avalia essa situaçảo?

Prof. Charles Beylier:

De fato, há um problema. Nāo coloquei no relato dessa experiência em Fortaleza, mas na realidade. a gente trabalha com a Assembléia de Deus. É uma colaboração um pouco difícil. mas na inauguração que fizemos antes de vir para cá. havia um representante dos protestantes evangélicos.

É verdade que a maneira de ver dos evangélicos é diferente da visāo que eu tenho, por exemplo. Pelo seguinte: é que esses novos movimentos, nāo só dos protestantes, mas dos carismáticos da Igreja Católica, dos judeus, dos islâmicos (eu diria também. de um certo modo, a visão de João XXIII, e de João Paulo Il. o Papa atual) têm uma maneira diferente de ver o papel da relação entre a modernização e a relıgıäo

Isso foi estudado por um sociólogo francês, do CNRS. que escreveu um livro que se chama "A Revanche de Deus" Nesse livro ele faz uma comparação entre religiōes que são extremamente diferentes. Porque o judaísmo, o islamismo, todas essas religiōes são bíblicas, isto é. elas têm em comum a Bíblia.

Ele nota o seguinte: enquanto, antes, as religiões procuravam se adaptar à modernidade, hoje, com a crise da modernidade, elas não procuram mais se adaptar. A modernidade já falhou, já demonstrou que é incapaz de ajudar o homem a viver.

Portanto. não é ela, não são os cientistas que têm a solução: são as religiōes que devem dizer aos cientıstas o que é e como é que eles deveriam fazer.

Há o que o autor chama de "revanche de Deus" Diante dessa natureza que se desmancha, que se destrói por si mesma, pela propria ganância do homem que só vê nela motıvo para lucrar, é preciso uma conversão da humanidade.

A Igreja é que tem o segredo da renovaçāo da humanidade e, portanto, também do controle do desabamento desta. Isso me sugere um fenômeno que a realidade parece confirmar. Não concordo com isso. Constato, simplesmente, que hoje, quando André Malraux disse que o séc. $X X \mid$ seria o século do sagrado, aliás o séc. $X X$ também, eu acho que há algo aí que é um fenômeno social, diante do progresso gigante da ciência e da tecnologia.

Prot. Carios Eduardo Zahn:

Não é nem uma pergunta, mas uma serıe de consideraçōes que eu queria que o senhor fizesse. a respeito de uma temática complexa que o senhor ievantou: a questäo do regionalismo.

O senhor disse, há pouco, que o regıonalismo é uma das manifestaçōes de necessidade de encontro da população com as suas raízes cuiturais. Na primeira parte da sua palestra. o senhor falou varıas vezes na questäo regionai, que a região modela os seus habitantes e que há uma necessıdade de se deixar modelar. dentro do pensamento de Roger Bastide. de se deixar penetrar pela cultura de onde se está

Tendo isso como pano de fundo, e tendo em vista o processo de ocupação do Brasil, que é um processo, de um lado. muito recente e, por outro, de ocupação tradicionalmente predatoria, a pergunta que fica e a seguınte: qual é a perspectiva de um regionalismo no Brasıl de hoje, tanto na escala do Brasil, como na de um Estado onde se tenta fazer e construir uma série de instituições. apesar desse quadro predatórı. desse quadro sem passado e sem raizes? 
Prof. Charles Beylier:

De fato, acho que é um problema difícil, complexo, sobretudo porque estamos justamente numa época de crise. De crise, como já falei: uma crise da racionalidade, uma crise da razão. Ela foi estudada por uma pessoa, por toda a Escola de Frankfurt, que se perguntou (e o último, o mais avançado, é Habermas) como é que um país, mais desenvolvido tecnica e culturalmente, também pode gerar o nazısmo, a matança de mılhares de judeus e o racısmo que se vê ultimamente que não morreu?

O que e a razäo humana. a crise da razão numana?

Isso foi apenas um dos aspectos questionados, mas eles continuaram. Com Habermas, especialmente, temos um pensador extremamente instigante e profundo.

Mas em todos, Adorno, Horkheimer, Benjamin, há uma visāo que me parece extremamente importante. Também para Ricouer a crise não é tanto da razão, como, do sentido, quer dizer: para quê?... para onde vai?... Esse sentido, que o positivismo quis eliminar, é a questão que nos devemos fazer. É a ciência que tem a resposta, e não adianta perguntar hoje, pois a cléncla não a pode dar. A eliminação de todo aspecto ético. pelo positivismo. chegou an que nós temos agora.

Retomando, acho que, nessa época de transição, não se pode definir muitas coisas; o que se pode é acompanhar. é questionar. Os valores estāo se esfacelando; não há mais os critérios que existiam antes: não existem da mesma maneira, agora. A concepçāo do amor e da familia mudou, como já falei. O pai de família, vocês sabem disso melhor do que eu, que quiser continuar a dizer: "eu falei e está falado" vai ver a criança rir, o jovem dizer: "você está quadrado?" Hoje, os pais falam e não está falado; o padre fala e não está falado: nāo tem mais esse negócio de "falado" Há, portanto. o diálogo. O jovem quer poder dialogar. Dialogar com o pai, com a māe! Se o pai e a mãe não aceitam, tanto faz: "deixa pra lá, não presta" Aí, vai dialogar com outros e outras.

Acho que aí há um enorme progresso da consciência humana. É a chance dos pais, que nāo conseguem mais mudar. de poderem se renovar no contato com seus próprios filhos, de sentirem, através deles, as mudanças que a sociedade está passando. E aceitarem que eles fazem besteiras. (A gente não faz?) Dizia-se que, nós, velhos, achamos que a nossa infância era perfeita.

Nunca falamos das besteiras que fizemos. E a gente fez as mesmas besteiras que eles. Acho que é bom ver essa mudança, muito rica de possibilidades e de ambigüidades: as coisas não estão feitas. Os jovens sāo o reservatório da étıca do Brasil, só eles acreditam nisso Talvez eles estejam muito enganados. mas, graças a Deus, eles ainda tém essa esperança: assim, peio menos, vāo ajudar o Brasil a caminhar, com a cara pintada de verde, amarelo ou preto.

É a maneira deles manifestarem sua alegrıa. o que são. o samba que eles dançam. ao mesmo tempo em que eles colocam o Collor num caixāo. Tudo isso mostra uma esperança muito grande na juventude do Brasıl.

O que eu quero dizer é que nāo tem resposta, a não ser descobrir essas coisas que estāo nascendo agora. A mudança da concepçāo do corpo e do sexo, fazendo parte do amor: repensar o dualısmo em que nós fomos criados. Não é para desvalorizar a sexualidade. mas para valorizá-la. Como sou padre quando falo. digo também cristamente: reencontrar o próprio corpo. que faz parte do nossc ser. 
Prof. José Luiz Caruso Ronca:

Como não há mais perguntas, em nome da Faculdade de Arquitetura e Urbanismo e da Comissão de Pós Graduação, agradeço a presença do Prof. Charles Beylier, que tanto enriqueceu esta inauguração da Sala Professor Dr. Luiz de Anhaia Mello.

Prof ${ }^{a}$ Gilda Collet Bruna:

Faço minhas as suas palavras. Espero que todos aproveitem a Sala Professor Luiz de Anhaia Mello. Muito obrigada.

\section{Bibliografia}

BASTIDE, Roger. Problèmes de la Vie Mystique. Paris: Armand Collin, 1931. 214p. Trad. Portuguesa. Lisboa, Europa-America, 1959. 181p.

\footnotetext{
_. Eléments de Sociologie Religieuse. Paris: Armand Collin, 1935. 204p.

Poetas Afro-Brasileiros. Sảo Paulo: Livraria Martins Ed., 1943. 158p.

Arte e Sociedade. São Paulo: Martins Ed., 1945. 252p.

Imagens do Nordeste Mistico em Branco e Preto. Rio de Janeiro: O Cruzeiro. 1945. 247p.

- Poetas do Brasil. Curitiba: Guaira. 150p.

- Le Candomblé de Bahia (rite Nagô). Paris: La Haye, Mouton e Cie, 1958. 260p.

. Les Religions Africaines au Brésil: Vers une Sociologie des Interpenétration de Civilisations. Paris: PUF, 1960. 578p. Trad. Maria Eloisa Capellato e Olivia Krahenbuhl. São Paulo: EDUSP 1971. 567p.

. Antropologia Aplicada. São Paulo: Perspectiva, 1979. $196 p$.
_. Anatomie d'André Gide. Paris: PUF 1972. 176p.
_. Estudos Afro-Brasileiros. Sāo Paulo: Perspectiva. Col. Ciências Sociais. 1973.
} $384 p$.

ESPAGNAT, Bernard d'. A La Recherche du Réel. Le Regard d'un Physicien. Paris: Bordas, $2^{\text {a }}$ Ed. 1981. 194p.

\section{Organizadores}

José Luiz Caruso Ronca

Professor Titular do Departamento de Projeto da FAUUSP

Presidente da Comissão de Pós-Graduação - FAUUSP (de abril de 1991 a fevereiro de 1994)

Carlos Eduardo Zahn

Prof. Dr. do Departamento de Projeto da FAUUSP

\section{Expositor}

Brenno Cyrino Nogueira

Prof. Dr. do Departamento de Projeto da FAUUSP

\section{Conferencista}

Charles Michel Marie Joseph Beylier

"École des Hautes Études en Sciences Sociales" - Paris - Doutor

Professor Adjunto no Curso de Mestrado em Sociologia

Universidade Federal do Ceará 